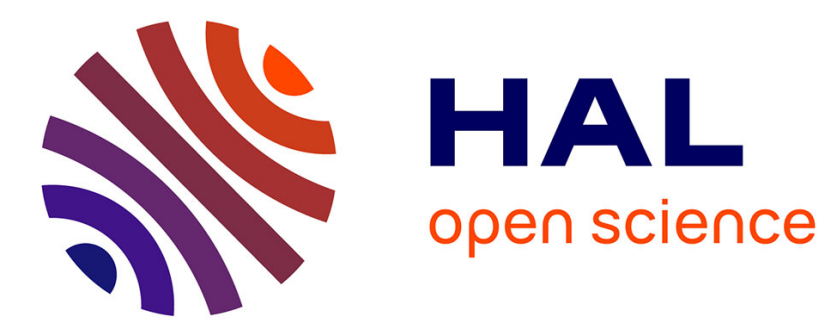

\title{
Thermal degradation of folates under varying oxygen conditions
}

Nicolas Delchier, Christiane Ringling, Marie-Elisabeth Cuvelier, Francis Courtois, Michael Rychlik, Catherine Renard

\section{- To cite this version:}

Nicolas Delchier, Christiane Ringling, Marie-Elisabeth Cuvelier, Francis Courtois, Michael Rychlik, et al.. Thermal degradation of folates under varying oxygen conditions. Food Chemistry, 2014, 165, pp.85-91. 10.1016/j.foodchem.2014.05.076 . hal-01173909

\section{HAL Id: hal-01173909 \\ https://hal.science/hal-01173909}

Submitted on 28 May 2020

HAL is a multi-disciplinary open access archive for the deposit and dissemination of scientific research documents, whether they are published or not. The documents may come from teaching and research institutions in France or abroad, or from public or private research centers.
L'archive ouverte pluridisciplinaire HAL, est destinée au dépôt et à la diffusion de documents scientifiques de niveau recherche, publiés ou non, émanant des établissements d'enseignement et de recherche français ou étrangers, des laboratoires publics ou privés. 


\title{
Thermal degradation of folates under varying oxygen conditions
}

\author{
Nicolas Delchier ${ }^{\mathrm{a}, \mathrm{b}}$, Christiane Ringling ${ }^{\mathrm{c}}$, Marie-Elisabeth Cuvelier ${ }^{\mathrm{d}, \mathrm{e}}$, Francis Courtois ${ }^{\mathrm{d}, \mathrm{e}}$, \\ Michael Rychlik ${ }^{\mathrm{c}, \mathrm{f}}$, Catherine M.G.C. Renard ${ }^{\mathrm{a}, \mathrm{b}, *}$ \\ a INRA, UMR408 Sécurité et Qualité des Produits d'Origine Végétale, Domaine Saint Paul, Site Agroparc, F-84000 Avignon, France \\ ${ }^{\mathrm{b}}$ Université d'Avignon et des Pays du Vaucluse, UMR408 Sécurité et Qualité des Produits d'Origine Végétale, F-84000 Avignon, France \\ ${ }^{\mathrm{c}}$ Bioanalytik Weihenstephan, Research Center of Nutrition and Food Sciences, Technische Universität München, Alte Akademie 10, D-85354 Freising, Germany \\ d AgroParisTech, UMR1145 Ingénierie Procédés Aliments, 1 Avenue des Olympiades, F-91300 Massy, France \\ e INRA, UMR1145 Ingénierie Procédés Aliments, 1 Avenue des Olympiades, F-91300 Massy, France \\ ${ }^{\mathrm{f}}$ Technische Universität München, Alte Akademie 10, D-85354 Freising, Germany
}

Keywords:

Vitamin

Heating

Vegetable

Oxidation

Spinach

Green bean

Kinetics

\begin{abstract}
A B S T R A C T
Folate losses in thermally treated foods are mainly due to oxidation. Other mechanisms and folate vitamers behaviour are poorly described.

Our study evaluated oxygen impact on total folate degradation and derivatives' evolution during thermal treatments.

Spinach and green bean purees were heated, in an instrumented reactor, in anaerobic conditions, under an oxygen partial pressure of $40 \mathrm{kPa}$.

Folates were stable in the absence of oxygen, whilst they were degraded under $40 \mathrm{kPa}$ of oxygen. Total folate showed a sharp decrease in the first hour driven by the degradation of $5-\mathrm{CH}_{3}-\mathrm{H}_{4}$ folate, followed by a plateau due to the formyl derivatives and minor compounds stability.

The different evolution of the main derivatives was confirmed by the degradation of 5- $\mathrm{CH}_{3}-\mathrm{H}_{4}$ folate and folic acid in solution, under the same conditions of oxygen concentrations. The stability of folic acid and the high susceptibility of $5-\mathrm{CH}_{3}-\mathrm{H}_{4}$ folate to degradation in the presence of oxygen were confirmed.
\end{abstract}

\section{Introduction}

Green vegetables are a good source of micronutrients, particularly of vitamins, and contribute to $40 \%$ of folate intake in the French diet (Lafay, 2009). Folates (vitamin B9) are well known to be involved in reducing the risk of neural tube defects (Czeizel \& Dudás, 1992). Green vegetables, such as spinach and green beans, are usually consumed cooked and frequently industrially processed. Industrial processing has a positive impact due to inactivation of microorganism and a negative impact linked to the reduction of micronutrients.

Heat treatments, such as blanching or boiling, leads to folate losses of $20-80 \%$ in spinach and from $0 \%$ to $20 \%$ in green beans (Delchier, Reich, \& Renard, 2012; DeSouza \& Eitenmiller, 1986; Klein, Lee, Reynolds, \& Wangles, 1979; McKillop et al., 2002; Melse-Boonstra et al., 2002). However, steaming and microwave cooking preserves folate content (Delchier et al., 2012; Klein

\footnotetext{
* Corresponding author: INRA - UMR 408 SQPOV, Domaine St Paul, Site Agroparc, F-84914 Avignon cédex 09, France. Tel.: +33 (0)4 327225 28; fax: +33 (0)4 32722492 .

E-mail address: catherine.renard@avignon.inra.fr (C.M.G.C. Renard).
}

et al., 1979; McKillop et al., 2002). One of the main mechanisms of folate losses is leaching to surrounding liquids (Scott, Rébeillé, \& Fletcher, 2000), as we confirmed from observations of industrial processing chains (Delchier et al., 2013), and from studying folate diffusion from whole spinach and green beans (Delchier, Ringling, Maingonnat, Rychlik, \& Renard, 2014).

Oxidation is the other main mechanism described in literature for folate loss. However, studies were carried out on model solutions and do not take strictly into account oxygen measurement, thus giving contrasting results. From 49 to $100{ }^{\circ} \mathrm{C}$, activation energy of $5-\mathrm{CH}_{3}-\mathrm{H}_{4}$ folate degradation was calculated as 39.74 $\mathrm{kJ} / \mathrm{mol}$ by Chen and Cooper (1979). In the same range of temperature and in presence or absence of oxygen, Barrett and Lund (1989) calculated activation energy as 68 and $97 \mathrm{~kJ} / \mathrm{mol}$, respectively, which is in the same order of magnitude as calculated by Viberg, Jägerstad, Öste, and Sjöholm (1997) $62 \mathrm{~kJ} / \mathrm{mol}$ in presence of oxygen and $106 \mathrm{~kJ} / \mathrm{mol}$ in absence of oxygen. Other studies on folate stability focussed on stability in different $\mathrm{pH}$ conditions. PaineWilson and Chen (1979) showed that pH has a profound influence on the thermal stability of folates, with optimal stability in neutral conditions. For $5-\mathrm{CH}_{3}-\mathrm{H}_{4}$ folate at $100{ }^{\circ} \mathrm{C}$, the time to decrease the initial content by half was $8.77 \mathrm{~min}$ at $\mathrm{pH} 7$ but 3.35 and 
Version définitive du manuscrit publiée dans / Final version of the manuscript published in :

Food Chemistry (2014), Vol. 165, p. 85-91, DOI: 10.1016/j.foodchem.2014.05.076

Journal homepage : www.elsevier.com/locate/foodchem

$3.45 \mathrm{~min}$ at $\mathrm{pH} 4$ and 10 , respectively. Indrawati, Verlinde, Ottoy, Van Loey, and Hendrickx (2004) determined the degradation rate constant $k$ at $90{ }^{\circ} \mathrm{C}$ for $5-\mathrm{CH}_{3}-\mathrm{H}_{4}$ folate in citrate-phosphate buffer $(\mathrm{pH} 4)$ as $115.08 \times 10^{-3} \mathrm{~min}^{-1}$ and in phosphate buffer ( $\left.\mathrm{pH} 7\right)$ as $68.31 \times 10^{-3} \mathrm{~min}^{-1}$. Folates thus appear to be quite vulnerable to heat, especially in slightly acidic conditions.

Our previous studies on folate degradation and diffusion in vegetable matrices under atmospheric conditions showed a different evolution depending on the nature of the derivatives. Moreover, total folate evolution during thermal degradation showed a non monotonous degradation in the beginning of the reaction kinetics and a plateau. Evolution of the different folate derivatives during thermal degradation seems to be a key point in the evolution of total folate.

The present study was designed to investigate the evolution of total folate and folate derivatives during thermal degradation of spinach and green bean purees. Moreover, in order to determine the role of oxygen, reaction kinetics were performed on vegetable purees and model solutions under two oxygen conditions (absence and twice the concentration in ambient atmosphere). For that, we used an instrumented reactor where all physico-chemical parameters, and especially oxygen, were strictly controlled.

\section{Materials and methods}

\subsection{Plant material}

Purees were prepared from canned spinach (net weight $265 \mathrm{~g}$; capacity $425 \mathrm{ml}$ ) and green beans (net weight $220 \mathrm{~g}$; capacity $425 \mathrm{ml}$ ), bought at a local supermarket. Cans were opened and vegetables were drained by sieving. $100 \mathrm{ml}$ of deionised water was added to $50 \mathrm{~g}$ of vegetables and ground with an ultraturax at $12,000 \mathrm{rpm}$ for $1 \mathrm{~min}$ (S25 18G, IKA, Staufen, Germany). Spinach purees were further diluted by half with deionised water.

\subsection{Stock solutions}

Folic acid and $5-\mathrm{CH}_{3}-\mathrm{H}_{4}$ folate were obtained from Schirks labs. (Jona, Switzerland). Stock solutions were prepared in phosphate citrate buffer ( $\mathrm{pH} 5 ; 0.1 \mathrm{~mol} / \mathrm{L}$ ), divided in $1 \mathrm{ml}$ aliquot and stored at $-20^{\circ} \mathrm{C}$ until experiments. Concentrations of stock solutions were $1 \times 10^{-4} \mathrm{~mol} / \mathrm{L}$, both for folic acid and $5-\mathrm{CH}_{3}-\mathrm{H}_{4}$ folate.

\subsection{Experimental device}

All reaction kinetics were performed in an instrumented reactor, composed of a thermostated chamber wherein the glass reactor was put (EasyMax, Mettler Toledo, Viroflay, France), a gas diluter (Gasmix, Alytech, Juvisy sur Orge, France) and an oxygen measurement apparatus (Fibox 3 LCD Trace, Presens, Regensburg, Germany).

Stirring was carried out using a cross-shaped magnetic bar with a length of $4 \mathrm{~cm}$ for each arm. The reactor had a glass plug with different apertures in order to introduce the temperature probe, condenser and sampling system, composed of a capillary hermetically bonded to a $10 \mathrm{ml}$ removable syringe.

Studies on folate degradation in model solutions or in purees of spinach or green beans were performed either in the presence of a gas composed of $40 \%$ of oxygen and $60 \%$ of nitrogen, giving a partial pressure of $40 \mathrm{kPa}$ of oxygen, or in anaerobic conditions (under a flow of $100 \%$ of nitrogen).

For experiments in the presence of $40 \mathrm{kPa}$ of oxygen, the gas mix was obtained using the gas diluter connected to nitrogen and oxygen cylinders. The associated software was used to prepare the gas mix, with an outlet flow rate of $322 \mathrm{ml} / \mathrm{min}$. For anaerobic experiments, nitrogen flow was directly introduced from cylinder into the reactor with a flow rate of $5.0 \mathrm{ml} / \mathrm{min}$.

In both cases, gas flow was applied into the reactor through a capillary and throughout the experiment. Oxygen concentration at the beginning, during and at the end of each reaction kinetic was determined using the oxygen sensor optical Fibox 3 LCD trace (Presens, Regensburg, Germany). This device allows a non-invasive measurement as the oxygen sensitive dye is immobilized in a sensor spot glued inside the glass reactor, and the measurement is done through the transparent wall of the glass reactor by using an optical fibre.

\subsection{Physico-chemical parameters}

Reaction kinetics were studied using the purees of spinach and green beans or solutions of $5-\mathrm{CH}_{3}-\mathrm{H}_{4}$ folate and folic acid in the $0.1 \mathrm{~mol} / \mathrm{L}$ phosphate buffer $\mathrm{pH} 7$ or $0.1 \mathrm{~mol} / \mathrm{L}$ phosphate citrate buffer pH 5 .

Two oxygen conditions were used,

(i) Under anaerobic conditions (flow of $100 \%$ of nitrogen).

(ii) In the presence of $40 \mathrm{kPa}$ of oxygen.

Reaction kinetics were performed at different temperatures:

(i) 45 and $65^{\circ} \mathrm{C}$ for purees in the presence of $40 \mathrm{kPa}$ of oxygen.

(ii) 45,65 and $85^{\circ} \mathrm{C}$ for purees under anaerobic conditions.

(iii) $25,45,65$ and $85{ }^{\circ} \mathrm{C}$ for folic acid and $5-\mathrm{CH}_{3}-\mathrm{H}_{4}$ folate solutions in the presence of $40 \mathrm{kPa}$ of oxygen and under anaerobic conditions.

\subsection{Reaction kinetics}

Buffers or purees were firstly bubbled at room temperature until the desired oxygen content was reached. Oxygen content was followed in buffers, purees and reactor's headspace using the Fibox 3LCD trace. Then, buffers or purees were heated until the temperature setpoint was reached.

At this moment, for spinach and green bean purees, reaction kinetics were started by sampling $2 \mathrm{ml}$ of purees which were directly put at $-20{ }^{\circ} \mathrm{C}$ and stored until analysis. For each condition (temperature and oxygen), 2 batches were independently followed during $4 \mathrm{~h}$. For folic acid and $5-\mathrm{CH}_{3}-\mathrm{H}_{4}$ folate solutions, reaction kinetics were started by adding $100 \mu \mathrm{l}$ of stock solutions to the buffer in the reactor for a final concentration of $1 \times 10^{-7} \mathrm{~mol} / \mathrm{L}$, an aliquot was immediately collected and stored at $-20^{\circ} \mathrm{C}$. Reaction kinetics were monitored during $3 \mathrm{~h}$.

Kinetic data was adjusted using a first order kinetics, directly fitted to the raw data. First order kinetics is described below (Eq. 1):

$C=C_{0} \times e^{(-k t)}$

where $C$ is the folate concentration, $C_{0}$ is the initial folate concentration, $k$ is the degradation rate constant and $t$ the time.

\subsection{Analytical procedures}

\subsubsection{Folic acid and $5-\mathrm{CH}_{3}-\mathrm{H}_{4}$ folate measurement}

A solution of ascorbic acid $(100 \mu \mathrm{l} ; 250 \mathrm{~g} / \mathrm{L})$ was added to $900 \mu \mathrm{l}$ of samples. Solutions of $5-\mathrm{CH}_{3}-\mathrm{H}_{4}$ folate were diluted 10 times in phosphate buffer ( $\mathrm{pH} 7 ; 0.1 \mathrm{~mol} / \mathrm{L})$ for HPLC analysis.

Folic acid and $5-\mathrm{CH}_{3}-\mathrm{H}_{4}$ folate quantification was carried out independently on a HPLC equipped with a Diode Array Detector (SPD-M-20A, Shimadzu, Kyoto, Japan) at $280 \mathrm{~nm}$ for folic acid and equipped with a fluorimetric detector (RF-10AXL, Shimadzu Inc., 
Kyoto, Japan) operated at an excitation wavelength of $295 \mathrm{~nm}$ and an emission wavelength of $356 \mathrm{~nm}$ for $5-\mathrm{CH}_{3}-\mathrm{H}_{4}$ folate. A LiChrospher 100RP-18 (250 $\times 4.5 \mathrm{~mm} ; 5 \mu \mathrm{m}$, Altech, France $)$ equipped with a guard column LiChrospher RP-18 All Guard $(7.5 \times 4.6 \mathrm{~mm}$; $5 \mu \mathrm{m}$, Altech, France) was used for the two compounds. The mobile phase was a gradient of water with formic acid $(10 \mathrm{ml} / \mathrm{L})$ and acetonitrile HPLC grade at a flow rate of $0.8 \mathrm{ml} / \mathrm{min}$. The injection volume was $100 \mu \mathrm{l}$ for folic acid and $25 \mu \mathrm{l}$ for $5-\mathrm{CH}_{3}-\mathrm{H}_{4}$ folate.

For folic acid the gradient used started at $5 \%$ of acetonitrile, increased linearly to $35 \%$ in $25 \mathrm{~min}$, then to $100 \%$ in $5 \mathrm{~min}$ and held for $10 \mathrm{~min}$, followed by a linear decrease to $5 \%$ in $5 \mathrm{~min}$. Column was equilibrated during $15 \mathrm{~min}$ at $5 \%$ of acetonitrile. Quantification was based on an external calibration against folic acid from $1 \times 10^{-9}$ to $1 \times 10^{-6} \mathrm{~mol} / \mathrm{L}\left(r^{2}=0.999\right)$.

For $5-\mathrm{CH}_{3}-\mathrm{H}_{4}$ folate the elution gradient started at $5 \%$ of acetonitrile, increased linearly to $100 \%$ in $25 \mathrm{~min}$, held for $10 \mathrm{~min}$, followed by linear decrease to $5 \%$ in $10 \mathrm{~min}$ and equilibrated for 10 min. Quantification was based on an external calibration against $5-\mathrm{CH}_{3}-\mathrm{H}_{4}$ folate monoglutamate from $1 \times 10^{-9}$ to $6 \times 10^{-8} \mathrm{~mol} / \mathrm{L}\left(r^{2}=0.996\right)$.

\subsubsection{Measurement of folate vitamers}

Individual folate vitamers were quantified by stable isotope dilution assay according to Ringling and Rychlik (2013). Briefly, before extraction, labelled standards of folate vitamers were added and all folates were deconjugated into their monoglutamate forms. Derivatives were purified on SPE SAX cartridges after adding acetonitrile $(10 \mathrm{ml})$ and centrifugation. Folate analysis was carried out on an HPLC (Shimadzu Inc., Kyoto, Japan) coupled with a triple quadrupole mass spectrometer (API 4000 Q-Trap, AB-Sciex, Foster City, CA, USA). A Pro-C18 HPLC-column $(150 \times 3,3 \mu \mathrm{m}, 130 \AA \AA$, YMC, Japan) with water plus $0.1 \%(\mathrm{v} / \mathrm{v})$ formic acid $(\mathrm{A})$ and acetonitrile plus $0.1 \%(\mathrm{v} / \mathrm{v})$ formic acid (B) as mobile phases was used. The gradient started at 5\% B. After a linear increase to $10 \% \mathrm{~B}$ and holding this condition for $5 \mathrm{~min}$, another linear increase to $15 \% \mathrm{~B}$ during $10 \mathrm{~min}$ and to $50 \% \mathrm{~B}$ in $2 \mathrm{~min}$, which was hold for $2 \mathrm{~min}$ followed. Within 2 min B was decreased linearly to $5 \%$ and the column was equilibrated for $9 \mathrm{~min}$.

Concentration of each single vitamer in the food samples was calculated using the response factors reported recently (Ringling \& Rychlik, 2013). For experimental details see Ringling and Rychlik (2013).

\subsection{Results expression}

Total folate amounts were determined by calculating the sum, in equivalent of folic acid, of folate derivatives $\left(5-\mathrm{CH}_{3}-\mathrm{H}_{4}\right.$ folate, 5-CHO- $\mathrm{H}_{4}$ folate, 10-CHO-PteGlu, folic acid, $\mathrm{H}_{4}$ folate, $5,10-\mathrm{CH}^{+}-\mathrm{H}_{4}$ folate and $10-\mathrm{CHO}-\mathrm{H}_{2}$ folate).

Results are expressed as $C / C_{0}$ calculated as the ratio between the concentration at the end of the reaction kinetics and the initial concentration.

\section{Results}

\subsection{Folate evolution in purees during thermal treatments under anaerobic conditions}

$C / C_{0}$ varied from 1.12 at $45^{\circ} \mathrm{C}$ to 1.09 at $85^{\circ} \mathrm{C}$ for spinach and was 1.02 both at 45 and $85^{\circ} \mathrm{C}$ for green beans. So, in anaerobic conditions there was no quantifiable folate degradation over $4 \mathrm{~h}$ neither in spinach nor in green beans, at 45,65 and $85^{\circ} \mathrm{C}$ (data not shown).

\subsection{Folate evolution in purees during thermal treatment in the presence of $40 \mathrm{kPa}$ of oxygen}

\subsubsection{Total folate}

For spinach, initial folate concentrations were relatively similar in all batches. However, for green beans, initial folate concentrations showed some variability between batches hence the expression in $C / C_{0}$.

For both vegetables studied, temperature had an effect on folate degradation, with a faster decrease between 0 and 60 min at $65^{\circ} \mathrm{C}$ than at $45^{\circ} \mathrm{C}$ (Fig. 1 ).

For spinach, the initial decrease with time was not monotonous. At $45^{\circ} \mathrm{C}$, folate concentrations seemed to increase during the first 5 min whereas at $65{ }^{\circ} \mathrm{C}$, after an initial sharp decrease, an increase was observed between 10 and $30 \mathrm{~min}$ (Fig. 1A and B). As for spinach, folate decrease in green beans was not monotonous, at $45^{\circ} \mathrm{C}$ total folate concentrations increased in the first minutes whereas at $65{ }^{\circ} \mathrm{C}$ folate concentrations increased between 10 and 30 min after a sharp decrease especially for one of the two batches (Fig. 1C and D).

For spinach, folates decreased until reaching a plateau at $90 \mathrm{~min}$ both at 45 and $65{ }^{\circ} \mathrm{C}$. Irrespective of the temperature, folate concentrations in green beans decreased during the thermal treatment in the presence of $40 \mathrm{kPa}$ of oxygen. A plateau was reached at 120 and $60 \mathrm{~min}$ at 45 and $65^{\circ} \mathrm{C}$, respectively.

Folate residual concentrations were $30 \%$ and $28 \%$ at $45{ }^{\circ} \mathrm{C}$ and $45 \%$ and $25 \%$ at $65{ }^{\circ} \mathrm{C}$ for spinach and green beans, respectively.

Folates were strongly degraded during thermal treatments in the presence of $40 \mathrm{kPa}$ of oxygen, thus confirming that oxygen was involved in folate degradation.

Because of this behaviour, linearisation of total folate decrease in spinach and green beans for all temperatures by first order with partial conversion or second order law was not satisfying. To understand the causes of this unexpected behaviour, individual vitamers were analysed.

\subsubsection{Evolution of the different folate vitamers}

3.2.2.1. 5- $\mathrm{CH}_{3}-\mathrm{H}_{4}$ folate. $5-\mathrm{CH}_{3}-\mathrm{H}_{4}$ folate represented $70 \%$ and $75 \%$ of total folate in spinach and green beans respectively, and was the predominantly degraded vitamer both in spinach and in green beans during kinetics (Supplementary data). Degradation of $5-\mathrm{CH}_{3}-\mathrm{H}_{4}$ folate was almost complete over the $4 \mathrm{~h}$ of thermal treatment for both vegetables and followed a first order law with a correlation coefficient of 0.96 and 0.99 at $45^{\circ} \mathrm{C}$ and 0.86 and 0.91 at $65^{\circ} \mathrm{C}$ for spinach and green beans, respectively (Fig. 2). The rate constants $k$ obtained were $25 \times 10^{-3}$ and $20 \times 10^{-3} \mathrm{~min}^{-1}$ at $45^{\circ} \mathrm{C}$ and $70 \times 10^{-3}$ and $80 \times 10^{-3} \mathrm{~min}^{-1}$ at $65^{\circ} \mathrm{C}$ for spinach and green beans, respectively.

After $4 \mathrm{~h}$ of incubation, $4.5 \%$ of the initial $5-\mathrm{CH}_{3}-\mathrm{H}_{4}$ folate was still present in spinach, both at 45 and $65{ }^{\circ} \mathrm{C}$, and $5.5 \%$ and $2 \%$ at $45^{\circ} \mathrm{C}$ and $65^{\circ} \mathrm{C}$ for green beans, respectively.

3.2.2.2. Formyl derivatives. Among formyl derivatives, 5-CHO- $\mathrm{H}_{4}$ folate represented about $15 \%$ of total folate and $10-\mathrm{CHO}-\mathrm{PteGlu}$ about $10 \%$ both in spinach and green beans. In spinach, $5-\mathrm{HCO}-\mathrm{H}_{4}$ folate concentrations increased in the first $30 \mathrm{~min}$ at $45^{\circ} \mathrm{C}$ and in the first $60 \mathrm{~min}$ at $65^{\circ} \mathrm{C}$ and then decreased to reach a plateau at $90 \mathrm{~min}$ for both temperatures. $88 \%$ of initial $5-\mathrm{CHO}-\mathrm{H}_{4}$ folate was still present in ground spinach after $4 \mathrm{~h}$ at $45^{\circ} \mathrm{C}$ and $82 \%$ at $65^{\circ} \mathrm{C}$. In green beans, $5-\mathrm{HCO}-\mathrm{H}_{4}$ folate was stable during the thermal treatment, with a slight decrease (up to $30 \mathrm{~min}$ ). Final concentrations of $5-\mathrm{HCO}-\mathrm{H}_{4}$ folate represented $96 \%$ of initial concentrations at $45{ }^{\circ} \mathrm{C}$ and $93 \%$ at $65^{\circ} \mathrm{C}$ (Fig. 3).

10-HCO-PteGlu was not degraded over $4 \mathrm{~h}$ thermal treatments in spinach. Actually, a slight increase in concentrations over time was observed. Concentrations at the end of the thermal treatment were $111 \%$ of the initial concentration both at 45 and $65{ }^{\circ} \mathrm{C}$. For 
Version définitive du manuscrit publiée dans / Final version of the manuscript published in :

Food Chemistry (2014), Vol. 165, p. 85-91, DOI: 10.1016/j.foodchem.2014.05.076

Journal homepage : www.elsevier.com/locate/foodchem
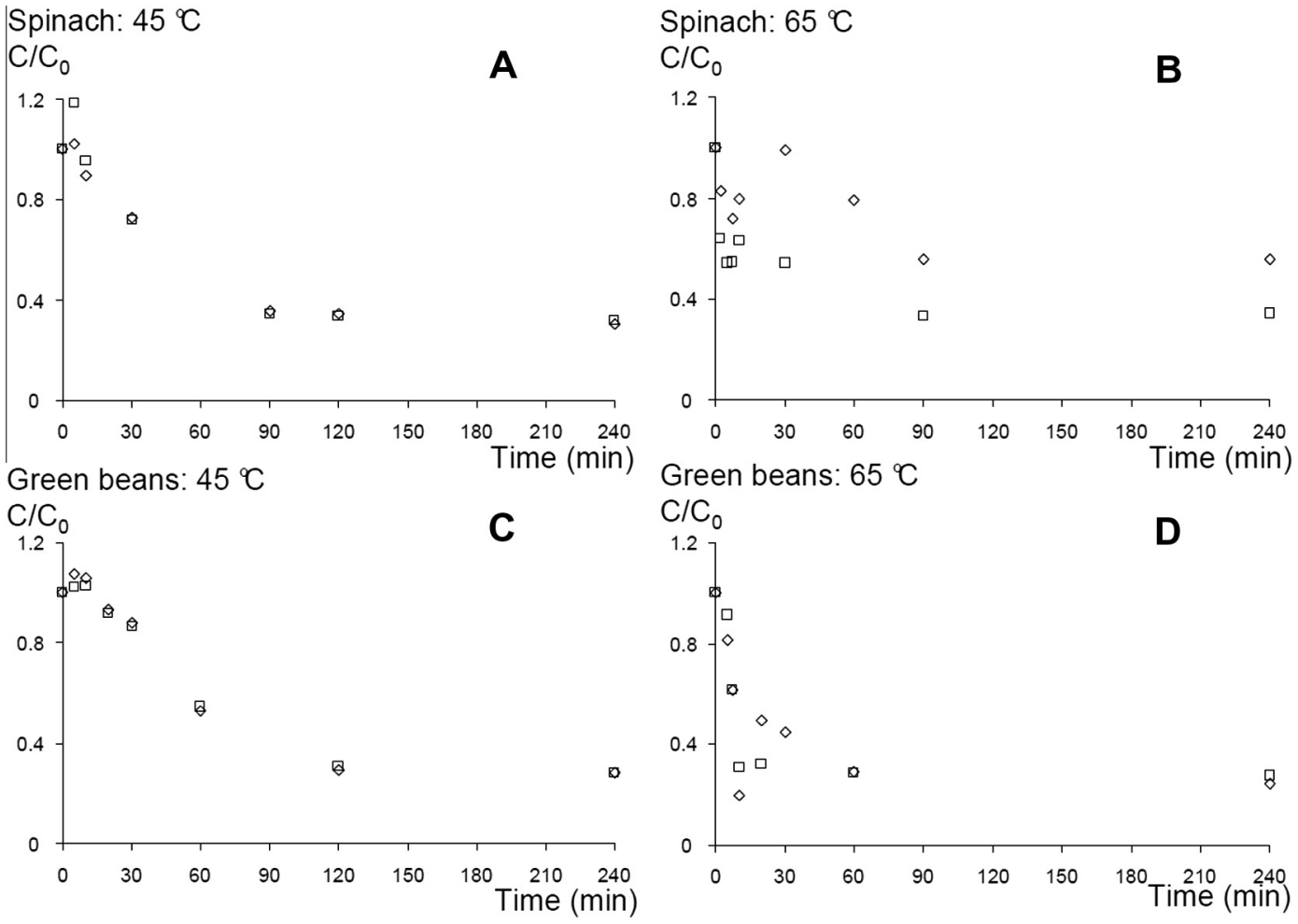

Fig. 1. Thermal degradation of total folate in spinach and green beans in presence of $40 \mathrm{kPa}$ of oxygen at 45 and $65{ }^{\circ} \mathrm{C}$. Thermal degradation assays of total folate represented by the ratio $C / C_{0}$ at 45 and $65^{\circ} \mathrm{C}$ in presence of $40 \mathrm{kPa}$ of oxygen are presented on the top for spinach (A and B) and on the bottom for green beans (C and D). For each temperature, $C / C_{0}$ of the two batches followed are presented, empty lozenge corresponding to the batch 1 and empty square to the batch 2 .
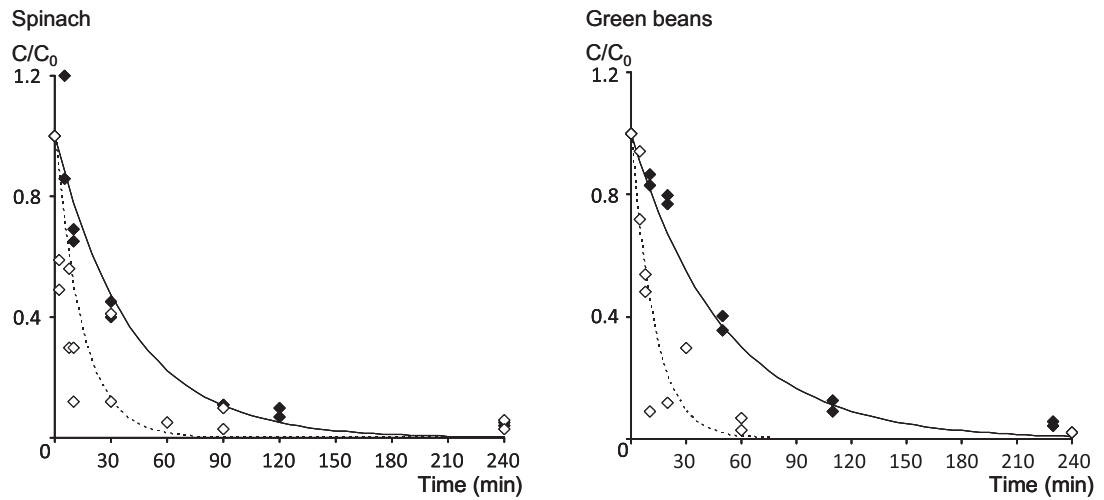

Fig. 2. Thermal degradation of $5-\mathrm{CH}_{3}-\mathrm{H}_{4}$ folate in spinach and green beans under $40 \mathrm{kPa}$ oxygen at 45 and $65{ }^{\circ} \mathrm{C}$. Evolution of $\mathrm{C} / \mathrm{C}_{0}$ of $5-\mathrm{CH}_{3}-\mathrm{H}_{4}$ folate under $40 \mathrm{kPa}$ of oxygen and first order kinetic fitting is presented on the left for spinach and on the right for green beans, at $45^{\circ} \mathrm{C}$ (full lozenges) and at $65^{\circ} \mathrm{C}$ (empty lozenges). Full line represents the first order kinetic model of thermal degradation at $45^{\circ} \mathrm{C}$, dot line at $65^{\circ} \mathrm{C}$.

green beans, concentrations of 10-HCO-PteGlu increased slightly over incubation. Final concentrations were $117 \%$ of the initial concentration at $45{ }^{\circ} \mathrm{C}$, and $108 \%$ at $65{ }^{\circ} \mathrm{C}$ (Fig. 3). Relative standard deviation for experiments at 45 and $65{ }^{\circ} \mathrm{C}$ varied from 0.01 to 0.12 for spinach and from 0.01 to 0.26 for green beans.

3.2.2.3. Minor derivatives. Minor derivatives in spinach and green beans (Supplementary data) were $\mathrm{H}_{4}$ folate; folic acid (PteGlu); $5,10-\mathrm{CH}^{+}-\mathrm{H}_{4}$ folate and $10-\mathrm{HCO}-\mathrm{H}_{2}$ folate, representing all together $5 \%$ of total folates. For these compounds, the very low and variable initial concentrations made interpretation difficult.

In spinach, behaviour of the four minor compounds was relatively different and in most cases their concentrations increased at the beginning of the thermal treatment and decreased at the end. Final concentrations of $\mathrm{H}_{4}$ folate were $60 \%$ of initial concentration for both 45 and $65^{\circ} \mathrm{C}$. Folic acid was relatively constant throughout the kinetics or increased slightly at $65^{\circ} \mathrm{C}$, with final concentrations of $96 \%$ at $45{ }^{\circ} \mathrm{C}$ and $111 \%$ at $65{ }^{\circ} \mathrm{C}$. Degradation of $5,10-\mathrm{CH}^{+}-\mathrm{H}_{4}$ folate was the same for both temperatures, with residual concentrations of about $70 \%$ of initial concentration. Finally, the 10-HCO- $\mathrm{H}_{2}$ folate decreased during the thermal treatment, with final concentrations on average of $70 \%$ of initial concentrations at $45^{\circ} \mathrm{C}$ and $45 \%$ at $65{ }^{\circ} \mathrm{C}$.

For green beans, folic acid, $5,10-\mathrm{CH}^{+}-\mathrm{H}_{4}$ folate, $\mathrm{H}_{4}$ folate and $10-$ $\mathrm{HCO}-\mathrm{H}_{2}$ folate were relatively variable throughout the kinetics but were globally quite stable during the reaction. 
Version définitive du manuscrit publiée dans / Final version of the manuscript published in :

Food Chemistry (2014), Vol. 165, p. 85-91, DOI: 10.1016/j.foodchem.2014.05.076

Journal homepage : www.elsevier.com/locate/foodchem

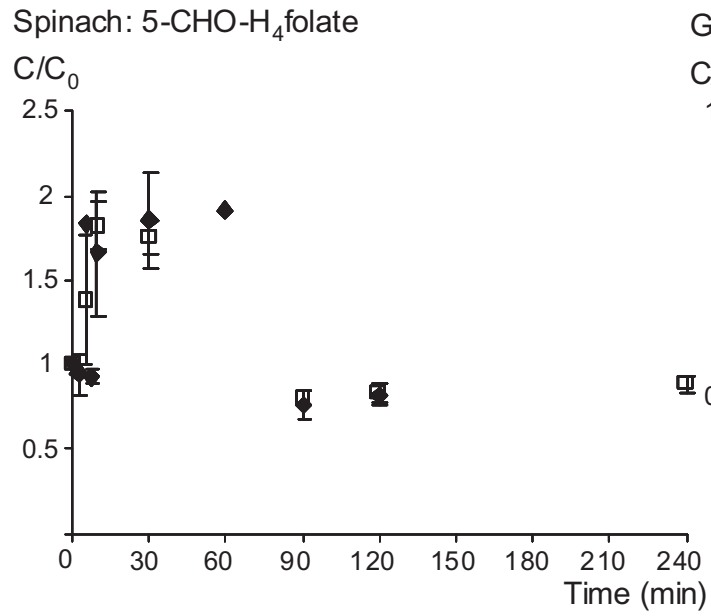

Green beans: $5-\mathrm{CHO}-\mathrm{H}_{4}$ folate

Spinach: 10-CHO-PteGlu

$\mathrm{C} / \mathrm{C}_{0}$

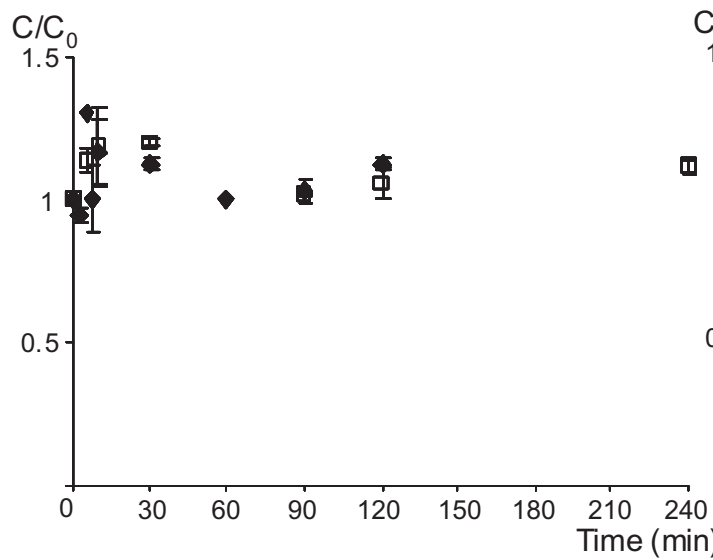

Green beans: 10-CHO-PteGlu

$\mathrm{C} / \mathrm{C}_{0}$

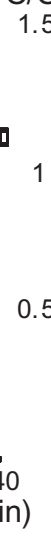

ㅍ

Time (min)

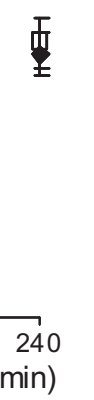

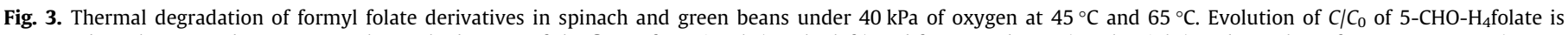

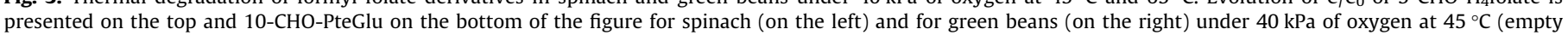
squares) and at $65{ }^{\circ} \mathrm{C}$ (full lozenges).

\subsection{Degradation in model solutions}

\subsubsection{Folic acid}

Folic acid was not degraded at 45,65 and $85^{\circ} \mathrm{C}$ under anaerobic conditions, neither at $\mathrm{pH} 5$ or 7 . In the presence of $40 \mathrm{kPa}$ of oxygen, it was stable at pH 5 and only limited degradation (circa $10 \%$ ) was observed at $\mathrm{pH} 7$ over $3 \mathrm{~h}$ of incubation (data not shown).

\subsection{2. $5-\mathrm{CH}_{3}-\mathrm{H}_{4}$ folate}

At $\mathrm{pH} 7$ and under anaerobic conditions, no consistent behaviour was obtained for $5-\mathrm{CH}_{3}-\mathrm{H}_{4}$ folate neither at $25{ }^{\circ} \mathrm{C}$ or at $85{ }^{\circ} \mathrm{C}$ (Table 1 ). At $\mathrm{pH} 5$, in some batches, its concentrations were stable (at $25^{\circ} \mathrm{C}$ ) while other showed a marked decrease, particularly rapid at $85{ }^{\circ} \mathrm{C}$. Obviously some uncontrolled factors were still present in the experiments.

In the presence of $40 \mathrm{kPa}$ of oxygen, $5-\mathrm{CH}_{3}-\mathrm{H}_{4}$ folate was degraded, both at pH 5 and 7 (Table 1). Residual concentrations of about $50 \%$ and $22 \%$ of initial concentrations were obtained after $3 \mathrm{~h}$ at $\mathrm{pH} 5$, at 65 and $85{ }^{\circ} \mathrm{C}$, respectively, while residual concentrations of about $5 \%$ of initial concentration were obtained at $\mathrm{pH} 7$ and $85^{\circ} \mathrm{C}$ after only 20 to $40 \mathrm{~min}$.

Further, a neo-formed product appeared on the HPLC traces (Fig. 4), while the peak of 5- $\mathrm{CH}_{3}-\mathrm{H}_{4}$ folate decreased markedly after only 2.5 min of incubation a slightly differently shaped peak reappears at the elution time after 10 min of incubation.

\section{Discussion and conclusion}

\subsection{Impact of oxygen on folate degradation}

Under anaerobic conditions in the media, folates were not degraded irrespective of the temperature applied $(45,65$ or $85^{\circ} \mathrm{C}$ ) neither in spinach, green bean purees or in model solutions. The presence of $40 \mathrm{kPa}$ of oxygen led to folate loss. Clearly oxygen was a factor for folate degradation during thermal treatment. However, the rate of folate loss was not doubled compared to our previous experiment under atmospheric (21 kPa oxygen) conditions (Delchier et al., 2014). Therefore, the exact role of oxygen (catalyst or reagent) and its stoichiometry still needs further investigation.

\subsection{Evolution of folate derivatives during thermal treatments}

Folate loss in spinach and green beans in the presence of $40 \mathrm{kPa}$ of oxygen followed neither a first order nor a second order reaction as classically described in literature for folate losses during heat treatment (Barrett \& Lund, 1989; Chen \& Cooper, 1979; Mnkeni \& Beveridge, 1983; Ruddick, Vanderstoep, \& Richards, 1980; Viberg et al., 1997). The two points of this diversion were (i) the existence of a plateau at long treatment durations and (ii) an apparent and transitory increase in the early stages of thermal treatment. The same plateau was reached at the three 
Version définitive du manuscrit publiée dans / Final version of the manuscript published in :

Food Chemistry (2014), Vol. 165, p. 85-91, DOI: 10.1016/j.foodchem.2014.05.076

Journal homepage : www.elsevier.com/locate/foodchem

Table 1

Evolution of $\mathrm{C} / \mathrm{C}_{0}$ of $5-\mathrm{CH}_{3}-\mathrm{H}_{4}$ folate in solution, under anaerobic and $40 \mathrm{kPa}$ oxygen, at pH 5 and 7, and at $25,45,65$ or $85{ }^{\circ} \mathrm{C}$.

\begin{tabular}{|c|c|c|c|c|c|c|c|c|c|c|c|}
\hline & \multirow[t]{2}{*}{$\mathrm{pH}$} & \multirow[t]{2}{*}{ Temperature $\left({ }^{\circ} \mathrm{C}\right)$} & \multirow[t]{2}{*}{ Batch } & \multicolumn{8}{|c|}{ Time (min) } \\
\hline & & & & 5 & 15 & 20 & 40 & 120 & 160 & 170 & 180 \\
\hline \multirow[t]{10}{*}{ Anaerobic } & 5 & 25 & 1 & & & & & & 1.07 & & \\
\hline & & 45 & 1 & & & & & & & & 1.06 \\
\hline & & 65 & 1 & & & & & & & & 0.93 \\
\hline & & 85 & 1 & & & & & & & & 1.02 \\
\hline & 7 & 25 & 1 & & & & & 0.98 & & & \\
\hline & & & 2 & & & & & & & & 1.21 \\
\hline & & & 3 & & & & & & & & $0.32^{a}$ \\
\hline & & 85 & 1 & $0.11^{a}$ & & & & & & & \\
\hline & & & 2 & & $0.38^{\mathrm{a}}$ & & & & & & \\
\hline & & & 3 & & & & & & & & 1.14 \\
\hline \multirow[t]{10}{*}{$40 \mathrm{kPa}$ oxygen } & 5 & 25 & 1 & & & & & 0.90 & & & \\
\hline & & & 2 & & & & & & & 0.85 & \\
\hline & & 65 & 1 & & & & & & & & 0.52 \\
\hline & & & 2 & & & & & & & & 0.51 \\
\hline & & 85 & 1 & & & & & & & & 0.29 \\
\hline & & & 2 & & & & & & & & 0.15 \\
\hline & 7 & 25 & 1 & & & & & & & & 0.81 \\
\hline & & 85 & 1 & & & & 0.05 & & & & \\
\hline & & & 2 & & & 0.04 & & & & & \\
\hline & & & 3 & 0.11 & & & & & & & \\
\hline
\end{tabular}

${ }^{\mathrm{a}}$ Unexplained result.

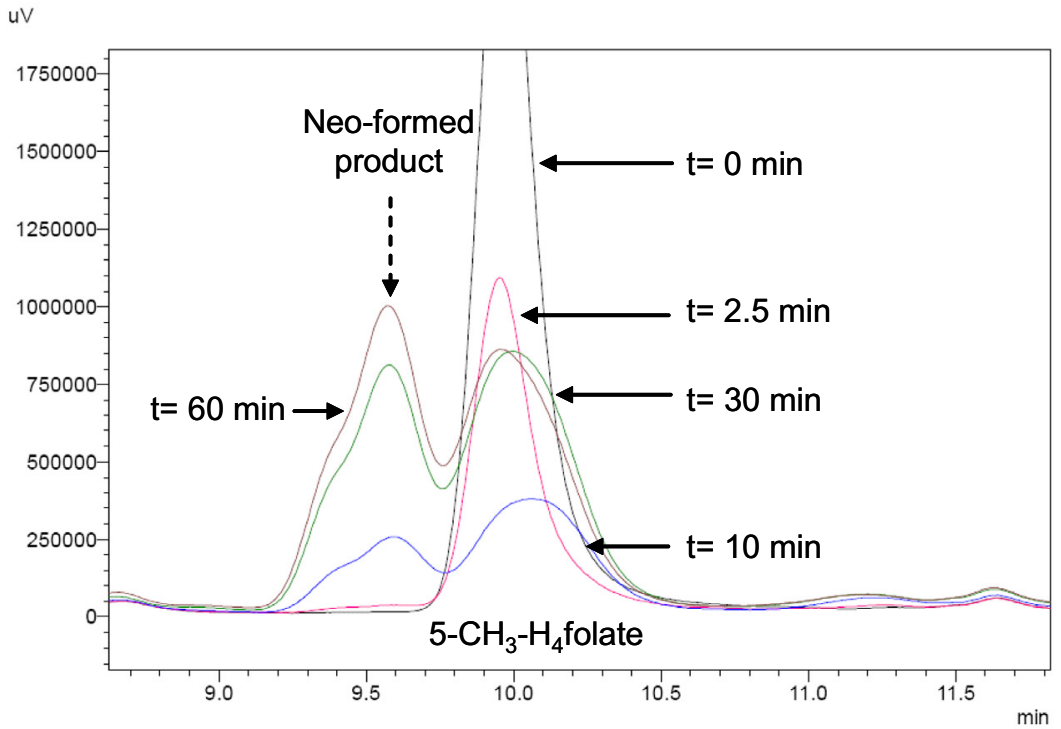

Fig. 4. Chromatograms of $5-\mathrm{CH}_{3}-\mathrm{H}_{4}$ folate solution over $60 \mathrm{~min}$ of thermal degradation under $40 \mathrm{kPa}$ oxygen at $85{ }^{\circ} \mathrm{C}$ and $\mathrm{pH} 7$.

temperatures used for spinach and green beans, though the initial rate of loss varied with temperature. This can be explained by the different evolution of folate derivatives, demonstrated by measuring the evolution of the different vitamers. In both vegetables, $5-\mathrm{CH}_{3}-\mathrm{H}_{4}$ folate was the main derivative, representing around $70 \%$ of total folate. Its evolution during incubation of the vegetables in the presence of $40 \mathrm{kPa}$ of oxygen followed first order kinetics, in agreement with data obtained in literature for folates (Barrett \& Lund, 1989; Chen \& Cooper, 1979; Mnkeni \& Beveridge, 1983; Oey, Verlinde, Hendrickx, \& Van Loey, 2006; Ruddick et al., 1980). The rate constants were close for both vegetables, and comparable to those found in the literature: $110 \times 10^{-3} \mathrm{~min}^{-1}$ at $100^{\circ} \mathrm{C}$ (Paine-Wilson \& Chen, 1979) $72 \times 10^{-3} \mathrm{~min}^{-1}$ at $100^{\circ} \mathrm{C}$ (Mnkeni \& Beveridge, 1983), $47 \times 10^{-3} \mathrm{~min}^{-1}$ at $60^{\circ} \mathrm{C}$ for the (6S) enantiomer (Oey et al., 2006). However, the evolution of other derivatives, such as $5-\mathrm{HCO}-\mathrm{H}_{4}$ folate and $10-\mathrm{HCO}-\mathrm{PteGlu}$, which represent 15 and $10 \%$ of total folate in spinach as well as 14 and $8 \%$ of total folate in green beans respectively, was different.
Those two compounds were stable, with a slight decrease at the end of the incubation for $5-\mathrm{HCO}-\mathrm{H}_{4}$ folate and increase for 10-HCO-PteGlu. Moreover, minor compounds (folic acid, 5, 10- $\mathrm{CH}^{+}-\mathrm{H}_{4}$ folate, $10-\mathrm{HCO}-\mathrm{H}_{2}$ folate and $\mathrm{H}_{4}$ folate) were globally stable during incubation over $3 \mathrm{~h}$ at $45-85^{\circ} \mathrm{C}$ in the presence of $40 \mathrm{kPa}$ of oxygen. Therefore, the stability of formyl and minor vitamers was responsible for the plateau observed during thermal treatments, whilst the decrease in total folate, in the beginning of the kinetics, was due to the degradation of $5-\mathrm{CH}_{3}-$ $\mathrm{H}_{4}$ folate.

\subsection{Folate degradation in model solutions}

To confirm this observation, two vitamers of contrasting behaviour, one highly degraded in vegetables purees $\left(5-\mathrm{CH}_{3}-\mathrm{H}_{4}\right.$ folate), and the other relatively stable (folic acid) were studied in solution at two different $\mathrm{pH}$ ( 5 and 7 ) and at temperatures from 25 to $85^{\circ} \mathrm{C}$. As the plateau of folate degradation in purees was reached in less 
Version définitive du manuscrit publiée dans / Final version of the manuscript published in :

Food Chemistry (2014), Vol. 165, p. 85-91, DOI: 10.1016/j.foodchem.2014.05.076

Journal homepage : www.elsevier.com/locate/foodchem

than $3 \mathrm{~h}$, the reaction kinetics of the 2 vitamers was followed only over $3 \mathrm{~h}$.

Folic acid was stable in all conditions tested (temperature, $\mathrm{pH}$ and oxygen content), in agreement with O'Broin et al. (1975) and Paine-Wilson \& Chen, 1979. 5- $\mathrm{CH}_{3}-\mathrm{H}_{4}$ folate was stable at $\mathrm{pH} 5$, when the medium is deprived of oxygen, and regardless of the temperature, again confirming the literature (Barrett \& Lund, 1989; O'Broin et al., 1975; Paine-Wilson \& Chen, 1979; Viberg et al., 1997). Marked degradation was observed for $5-\mathrm{CH}_{3}-\mathrm{H}_{4}$ folate at $\mathrm{pH} 5$ and 7 and in the presence of $40 \mathrm{kPa}$ of oxygen, particularly at high temperatures. Under these conditions, its degradation was more rapid than in the vegetables, which could be due to a protective effect of the plant matrices. One of the degradation products which we obtain was slightly more hydrophilic than $5-\mathrm{CH}_{3}-\mathrm{H}_{4}$ folate (earlier elution on $\mathrm{C} 18$ column) but with similar fluorescence properties.

\section{Acknowledgement}

This work benefited from financial support of ANR-09-ALIA-014 RIBENUT Project: New approaches for microbial risk - nutritional benefits assessment in the case of heat processed vegetables.

\section{References}

Barrett, D. M., \& Lund, D. B. (1989). Effect of oxygen on thermal degradation of 5-methyl-5,6,7,8-tetrahydrofolic acid. Journal of Food Science, 54(1), 146-149.

Chen, T. S., \& Cooper, R. G. (1979). Thermal destructuration of folacin: Effect of ascorbic acid, oxygen and temperature. Journal of Food Science, 44(3), 713-716.

Czeizel, A. E., \& Dudás, I. (1992). Prevention of the first occurrence of neural-tube defects by periconceptional vitamin supplementation. New England Journal of Medicine, 327(26), 1832-1835.

Delchier, N., Reich, M., \& Renard, C. M. G. C. (2012). Impact of cooking methods on folates, ascorbic acid and lutein in green beans (Phaseolus vulgaris) and spinach (Spinacea oleracea). LWT - Food Science and Technology, 49, 197-201.
Delchier, N., Ringling, C., Maingonnat, J.-F., Rychlik, M., Renard, C. M. G. C. (2014). Mechanisms of folates losses during processing: Diffusion vs. heat degradation. Food Chemistry (submitted for publication).

Delchier, N., Ringling, C., Le Grandois, J., Aoudé-Werner, D., Galland, R., Georgé, S., et al. (2013). Effects of industrial processing on folate content in green vegetables. Food Chemistry, 139, 815-824.

DeSouza, S. C., \& Eitenmiller, R. R. (1986). Effects of processing and storage on the folate content of spinach and broccoli. Journal of Food Science, 51(3), 626-628.

Indrawati Verlinde, P., Ottoy, F., Van Loey, A., \& Hendrickx, M. (2004). Implications of $\beta$-mercaptoethanol in relation to folate stability and to determination of folate degradation kinetics during processing: A case study on [6S]-5methyltetrahydrofolic acid. Journal of Agricultural and Food Chemistry, 52(26), 8247-8254.

Klein, B. P., Lee, H. C., Reynolds, P. A., \& Wangles, N. C. (1979). Folacin content of microwave and conventionally cooked frozen vegetables. Journal of Food Science, 44(1), 286-288.

Lafay, L. (2009). Etude Individuelle Nationale des Consommations Alimentaires 2 (INCA-2). <http://www.anses.fr/Documents/PASER-Ra-INCA2.pdf> (in french), uploaded January 2012.

McKillop, D. J., Pentieva, K., Daly, D., McPartlin, J. M., Hughes, J., Strain, J. J., et al. (2002). The effect of different cooking methods on folate retention in various foods that are amongst the major contributors to folate intake in the UK diet. British Journal of Nutrition, 88(06), 681-688.

Melse-Boonstra, A., Verhoef, P., Konings, E. J. M., van Dusseldorp, M., Matser, A., Hollman, P. C. H., et al. (2002). Influence of processing on total, monoglutamate and polyglutamate folate contents of leeks, cauliflower, and green beans. Journal of Agricultural and Food Chemistry, 50(12), 3473-3478.

Mnkeni, A. P., \& Beveridge, T. (1983). Thermal destruction of 5-methyltetrahydrofolic acid in buffer and model food systems. Journal of Food Science, 48(2), 595-599.

O’Broin, J. D., Temperley, I. J., Brown, J. P., \& Scott, J. M. (1975). Nutritional stability of various naturally occurring monoglutamate derivatives of folic acid. The American Journal of Clinical Nutrition, 28(5), 438-444.

Oey, I., Verlinde, P., Hendrickx, M., \& Van Loey, A. (2006). Temperature and pressure stability of L-ascorbic acid and/or [6s]5-methyltetrahydrofolic acid: A kinetic study. European Food Research and Technology, 223(1), 71-77.

Paine-Wilson, B., \& Chen, T.-S. (1979). Thermal destruction of folacin: Effect of pH and buffer ions. Journal of Food Science, 44(3), 717-722.

Ringling, C., \& Rychlik, M. (2013). Analysis of seven folates in food by LC-MS/MS to improve accuracy of total folate data. European Food Research and Technology, 236, 17-28.

Ruddick, J. E., Vanderstoep, J., \& Richards, J. F. (1980). Kinetics of thermal degradation of methyltetrahydrofolic acid. Journal of Food Science, 45(4), 1019-1022.

Scott, J., Rébeillé, F., \& Fletcher, J. (2000). Folic acid and folates: the feasibility for nutritional enhancement in plant foods. Journal of the Science of Food and Agriculture, 80(7), 795-824.

Viberg, U., Jägerstad, M., Öste, R., \& Sjöholm, I. (1997). Thermal processing of 5 -methyltetrahydrofolic acid in the UHT region in the presence of oxygen. Food Chemistry, 59(3), 381-386. 